Revista Brasil. Bot., V.25, n.1, p.93-101, mar. 2002

\title{
Effects of using different host plants on the detected biodiversity of arbuscular mycorrhizal fungi from an agroecosystem ${ }^{1}$
}

\author{
ROSILAINE CARRENHO ${ }^{2}$, SANDRA F.B. TRUFEM ${ }^{3}$ and VERA L.R. BONONI ${ }^{3}$
}

(received: November 21, 2000; accepted: January 11, 2002)

\begin{abstract}
Effects of using different host plants on the detected biodiversity of arbuscular mycorrhizal fungi from an agroecosystem). The influence of peanut (Arachis hypogaea L.), sorghum (Sorghum bicolor (L.) Moench) and maize (Zea mays L.) on the development and diversity of arbuscular mycorrhizal fungi (AMF) from an agrosystem was investigated. Soil collected from an agricultural field where maize had been grown was inserted into sowing holes, under the seeds of peanut, sorghum and maize those were subsequently grown in sterilised quartz sand separately in plastic boxes for five months. After this period, collections of roots and rhizospheric soil were made to evaluate the percentages of root colonization (RC), number of spores (NS) and species of AMF. Peanut showed the highest average values for RC and NS: 24.5\% and 547.8/100 g of soil, respectively. Maize had an average RC of $19.7 \%$ and 415.2 spores $/ 100 \mathrm{~g}$ soil. Sorghum showed the lowest values: $15.9 \%$ for average $\mathrm{RC}$ and 349.8 spores/100 $\mathrm{g}$ soil. A total of fourteen species of AMF were identified. Seven species were identified from peanut rhizospheres, Entrophospora colombiana being the most abundant and frequent. In sorghum rhizospheres, twelve species were found, Glomus geosporum was the dominant taxon in terms of number of spores and frequency. Ten species were detected in maize with Acaulospora longula being the most abundant and the most frequent. It was observed that peanut was the best plant for promoting the sporulation of AMF, while sorghum favoured the establishment of most AMF species, followed by maize.
\end{abstract}

RESUMO - (Efeitos do uso de diferentes plantas hospedeiras na biodiversidade detectada de fungos micorrízicos arbusculares de um agroecossistema). O objetivo deste trabalho foi estudar a influência de amendoim (Arachis hypogaea L.), sorgo (Sorghum bicolor (L.) Moench) e milho (Zea mays L.) sobre o desenvolvimento e diversidade de fungos micorrízicos arbusculares (FMA). Esporos de FMA, multiplicados anteriormente em milho, foram depositados sob sementes de amendoim, sorgo ou milho em caixas plásticas contendo areia de rio esterilizada. Cinco meses depois, amostras de raízes e solo rizosférico das três plantas hospedeiras foram coletadas para avaliar-se os parâmetros: colonização radical (CR), número de esporos (NE) e diversidade de espécies de FMA. Amendoim apresentou os valores mais altos de CR e NE: 24,5\% e 547,8/100 g solo, respectivamente; milho teve valores menores para CR e NE: 19,7\% e 415,2 esporos/100g solo, respectivamente; e sorgo apresentou em média 15,9\% de CR e 349,8 esporos/100 g solo. Ao todo, foram isoladas e identificadas quatorze espécies de FMA. Sete foram verificadas em milho, sendo Entrophospora colombiana a mais abundante e freqüente. Em sorgo verificou-se 12 espécies, sendo Glomus geosporum o táxon dominante. Em milho foram isoladas dez espécies, sendo Acaulospora longula a mais abundante e freqüente. Pôde-se observar também que amendoim foi a planta que mais promoveu a esporulação dos FMA, enquanto sorgo favoreceu o estabelecimento de maior número de espécies de FMA.

Key words - Peanut, sorghum, maize, diversity of species

\section{Introduction}

Associations between arbuscular mycorrhizal fungi (AMF) and roots are generally considered to be nonspecific (Mosse 1975). However, this does not eliminate the possibility of a photobiont exposed to several species of AMF being preferentially colonized by one of them.

Host plants may control the development of arbuscular mycorrhizal genetically (Lackie et al.

\footnotetext{
1. Part of the PhD thesis of the first author

2. Universidade Estadual de Maringá, Departamento de Biologia, Campus Universitário, Av. Colombo 5790, 87020-900 Maringá, PR, Brazil.

3. Instituto de Botânica, Seção de Micologia, Caixa Postal 4005, 01061-970 São Paulo, SP, Brazil.

4. Corresponding author: rcarrenho@uem.br
}

1987) and by means of their own development.

The relation between the vigour of a photobiont and production of spores by AMF is well documented (Chilvers \& Daft 1982). Reduced vigour tends to diminish sporulation and this may be followed by a decrease in the richness of species. Typically, the maximal numbers of spores have been observed when the host plants had their maximal dry weight (Simpson \& Daft 1990).

Factors that restrict photosynthesis, such as light intensity reduction and defoliation, have been reported to reduce both root colonization and the formation of vesicles (Bethlenfalvay \& Pacovszcky 1983, Same et al. 1983) and may also affect the development of external hyphae and spore production.

Spore germination is generally stimulated by root exudates from mycotrophic plants; however, some non- 
mycorrhizal plants, such as Brassica spp., have exudates that reduce the germination of spores (Smith \& Read 1997).

Information on the association of specific AMF with specific host plants is scarce and the data are ambiguous. For example, Howeler et al. (1987) observed that leguminous plants produced more AMF spores than grasses, while Simpson \& Daft (1990) observed the opposite: greater sporulation of Glomus clarum in sorghum and millet than in peanut and chickpea. Moreover, while some species of AMF have a wide distribution among host plants, others have been found in rhizospheres of a single host plant, such as Acaulospora splendida in Quercus costaricensis (Sieverding 1991).

Depending on the cultivation practices used for plant growth, type of substrate and host plants, and the environmental conditions, the competitive ability of the AMF present in the initial population may change, resulting in different quantitative and qualitative composition of the community. Thus, the establishment of preferential associations between plants and AMF may be mediated by the interaction between plant, environment and fungi, rather than by the plant alone, and these relationships may interfere with the process of collection and multiplication of species in pots, making the determination of real diversity in AMF communities established in the field impossible.

The goal of this study was to evaluate the influence of different host plants (peanut, maize and sorghum) grown in an acidic poor substrate (quartz sand) on the development of AMF (root colonization and sporulation) and on the diversity of AMF species.

\section{Materials and methods}

Experimental area - The experimental area is located in the Biological Reserve and Experimental Station of Moji-Guaçu, Martinho Prado, São Paulo State, at $22^{\circ} 18^{\prime} \mathrm{S}$ and $47^{\circ} 11^{\prime} \mathrm{W}$, at an elevation of $680 \mathrm{~m}$; the climate is Cwa type, according to the Köppen classification, with dry winters and average temperatures close to $16{ }^{\circ} \mathrm{C}$ in the coldest month and to $24{ }^{\circ} \mathrm{C}$ in the hottest month (Baptista 1988).

Inoculum production - Soil samples (approximately $3 \mathrm{~kg}$ ) were collected from the experimental area, which had been previously used for maize cultivation. The samples were mixed and homogenized manually, then they were processed by wet sieving with sieves of mesh sizes $0.71 \mathrm{~mm}$ and $0.053 \mathrm{~mm}$. This concentrated the spores and excluded coarse soil particles, organic debris and roots. The material retained in the second sieve was deposited into plastic boxes, dried at room temperature, placed into clean plastic bags and kept at $5{ }^{\circ} \mathrm{C}$ until use. The remaining soil samples were separated into subsamples and processed by wet sieving (to isolate AMF spores) according to Gerdemann \& Nicolson (1963). The extracted spores were mounted on semi-permanent slides (PVLG) and identified to specific level. Each $5 \mathrm{~g}$ of inoculum contained approximately 32 spores representing the following species: Acaulospora appendicula, A. scrobiculata, Gigaspora decipiens, G. margarita, Glomus macrocarpum, G. invermaium, Scutellospora heterogama and S. persica.

Photobionts - The plants studied in this experiment were: maize (Zea mays L. cv. 'IAC Taiúba'), peanut (Arachis hypogaea L. cv. "tatu" and sorghum (Sorghum bicolor (L.) Moench cv. "AG 1017"). These species were chosen because they are economically important crops in Brazil and all of them have been previously used for multiplication of AMF spores.

Growth substrate - The material used as a substrate for plant growth and the production of spores of AMF was quartz sand. The sand was sterilized with methyl bromide, one month prior to the start of the experiment. Granulometric analysis revealed the following mineral fractions: clay $4 \%$, silt $8 \%$, fine sand $9 \%$ and coarse sand $79 \%$. Chemical analysis showed the following characteristics: $\mathrm{pH}\left(\mathrm{CaCl}_{2}\right)$ 5.0, P $10 \mathrm{mg} . \mathrm{dm}^{-3}$, O.M. 4 g.dm ${ }^{-3}$ and in mmolc. dm ${ }^{-3}: \mathrm{K}=0.06, \mathrm{Ca}=0.5, \mathrm{Mg}=0.1, \mathrm{H}+\mathrm{Al}$ $=1.2, \mathrm{SB}=0.7, \mathrm{IEC}=1.9$ and $\mathrm{V}=350 \mathrm{~g} \cdot \mathrm{dm}^{-3}$. The micronutrient concentrations (mg. $\mathrm{g}^{-1}$ ) were: $\mathrm{Cu}=0.4 ; \mathrm{B}=0.12 ; \mathrm{Fe}=73 ; \mathrm{Mn}$ $=26.1 ; \mathrm{Zn}=1.3 ; \mathrm{Cd}=0.001 ; \mathrm{Cr}=0.002 ; \mathrm{Ni}=0.08 ; \mathrm{Pb}=0.81$. Installation - The experiment was started in the middle of May (1995), one month after sand fumigation. Plastic boxes, with holes in the bottom, were filled with quartz sand to approximately $2 / 3$ of their volume. Seeds of peanut, sorghum and maize were sown after introduction of $5 \mathrm{~g}$ of AMF inoculum. The inoculum was inserted in the bottom of the holes and two seeds were placed immediately above; then each hole was fertilized with $10 \mathrm{ml}$ of Hoagland's solution.

For each host species a different sowing pattern was adopted, taking into consideration the size of the plant and the morphology of the root system:

a) for peanut, boxes $38 \mathrm{~cm}$ long $\times 32 \mathrm{~cm}$ wide $\times 6 \mathrm{~cm}$ deep were used with spacing of $6 \mathrm{~cm} \times 6 \mathrm{~cm}$ between the adjacent sowing holes (each approximately $5 \mathrm{~cm}$ deep);

b) for sorghum, the boxes were $44 \mathrm{~cm}$ long $\times 32 \mathrm{~cm}$ wide $\times$ $20 \mathrm{~cm}$ deep with spacing of $6 \mathrm{~cm} \times 8 \mathrm{~cm}$ (width $\mathrm{x}$ length) between the holes; holes were approximately $8 \mathrm{~cm}$ deep;

c) for maize, the boxes were $48 \mathrm{~cm}$ long $\times 32 \mathrm{~cm}$ wide $\times 30 \mathrm{~cm}$ deep with spacing $10 \mathrm{~cm} \times 12 \mathrm{~cm}$ (width $\mathrm{x}$ length) between the holes (each $15 \mathrm{~cm}$ deep).

After inoculation and sowing, the boxes were placed onto metallic tables in the field; each table was occupied by boxes of only one photobiont species.

Two weeks after the emergence of the seedlings, the less vigorous ones were removed. The plants were watered daily for five months and then not watered for a week to stress the plants and stimulate spore production of associated AMF.

The experiment was set up in a completely randomised design. Each replicate consisted of a plastic box used for the multiplication of AMF spores, with three photobiont species 
(peanut, sorghum and maize). For each host species, six multiplication boxes were prepared. From each box, one compound sample of rhizospheric soil from three plants was made. With these six samples, the data (root colonization and number of spores) were statistically analysed.

Fertilization practices - Applications of Hoagland's solution were made during the whole experimental period. In the first month, each plant received $10 \mathrm{ml}$ of solution (weekly). In the second month, the $10 \mathrm{ml}$ applications were made twice a week. In the third month, fertilization with ammonium sulphate, simple superphosphate and potassium chloride (4:14:8) was made. The fertilizers were dissolved in water $\left(100 \mathrm{~g} . \mathrm{L}^{-1}\right)$, and $30 \mathrm{ml}$ of this solution were applied to each plant, corresponding to $0.12 \mathrm{~g}$ of $\mathrm{N}, 0.42 \mathrm{~g}$ of $\mathrm{P}_{2} \mathrm{O}_{5}$ and $0.2 \mathrm{mg}$ of $\mathrm{K}_{2} \mathrm{O}$. One week later, each plant received $20 \mathrm{ml}$ of the same NPK solution. In the next months, $10 \mathrm{ml}$ of Hoagland solution were applied twice a week. Weeding at weekly intervals was carried out by hand. Harvesting - After water stress, shoots were removed and the boxes were taken to the laboratory, where the roots were separated from the substrate and the finer ones were selected and kept in Wheaton flasks. About $1.5 \mathrm{~g}$ of these roots were cleared and stained with trypan blue for evaluation of root colonization (Phillips \& Hayman 1970). Samples of $100 \mathrm{ml}$ of sand from three different points were taken from each box and used to form a compound sample. These samples were processed individually and the spores of AMF were isolated, counted and identified.

Analysed parameters - Root colonization was measured by gridline intersection (Giovannetti \& Mosse 1980). Total number of spores refers to all of the spores isolated from $100 \mathrm{~g}$ of dry soil and the relative number refers to the relationship between the number of spores of individual species and the total number observed. Relative frequency of occurrence is the relationship between the number of times a species was observed and the total number of samples studied. The richness of species was evaluated in two ways: simply as the relationship between the number of species and the size of the sample (100 $\mathrm{g}$ of dry soil), and also by counting the number of species from each family. Dominance was estimated using Simpson's index (Simpson 1949); for diversity we used the index of Shannon \& Weaver (1949) and for equability we used the index J' (Pielou 1975).

Statistical analysis - In order to normalize the data, those for root colonization were transformed to the arcsine of the squared root of $\mathrm{x} / 100$, where $\mathrm{x}$ represents the percentage obtained in the quantification. The numbers of spores were transformed to $\log \mathrm{x}$. Analysis of variance (ANOVA) was performed on percent root colonization and number of spores. Means comparisons were made between the data obtained for each box using Tukey's test $(\mathrm{P} \leq 0.05)$.

\section{Results and Discussion}

Root colonization - The percent root colonisation levels were low (table 1), when compared to those observed
Table 1. Root colonization by AMF and number of spores in peanut, sorghum and maize grown in quartz sand.

\begin{tabular}{|c|c|c|c|c|c|c|}
\hline \multirow[t]{2}{*}{ Replicate } & \multicolumn{3}{|c|}{ Root colonization $(\%)$} & \multicolumn{3}{|c|}{ Number of spores $/ 100 \mathrm{~g}$ soil } \\
\hline & Peanut & Sorghum & $\overline{\text { Maize }}$ & Peanut & Sorghum & $\overline{\text { Maize }}$ \\
\hline 1 & 30.5 & 16.7 & 21.0 & 505 & 291 & 365 \\
\hline 2 & 29.8 & 9.5 & 12.3 & 652 & 346 & 424 \\
\hline 3 & 20.7 & 15.5 & 26.3 & 597 & 285 & 436 \\
\hline 4 & 20.9 & 11.4 & 14.8 & 613 & 400 & 388 \\
\hline 5 & 21.4 & 23.9 & 24.6 & 498 & 380 & 425 \\
\hline 6 & 23.7 & 18.2 & 19.3 & 422 & 397 & 453 \\
\hline$\overline{\mathrm{X}}$ & 24.5 & 15.9 & 19.7 & 547.8 & 349.8 & 415.2 \\
\hline
\end{tabular}

for the same host plants, under different cropping systems (Bononi et al. 1988, Barbosa \& Santos 1991, Graciolli 1992, Gomes-da-Costa 1993). These low values may result from poor production and limited drain of photoassimilates for the mycobionts, as a response by the plant to the limited availability of mineral nutrients $\left(\mathrm{P}=10 \mathrm{mg} \cdot \mathrm{dm}^{-3} ; \mathrm{K}=0.06 \mathrm{mg} \cdot \mathrm{dm}^{-3} ; \mathrm{Mg}=0.1 \mathrm{mg} \cdot \mathrm{dm}^{-3}\right)$, due to the low $\mathrm{pH}$ of the substrate.

Peanut exhibited the highest values for root colonization, which ranged from 20.7 to $30.5 \%$. Maize and sorghum had percentages ranging from 12.3 to $26.3 \%$, and from 9.5 to $23.9 \%$, respectively. The differences observed between peanut and the two grasses were statistically significant (figure 1).

The higher root percent colonization rates observed for peanut may have been due to the composition of its root exudates. Redmond et al. (1986) demonstrated that some flavones are produced exclusively by leguminous plants and D'arcy-Lameta (1988) observed that different legumes produce different types of flavonoids. These

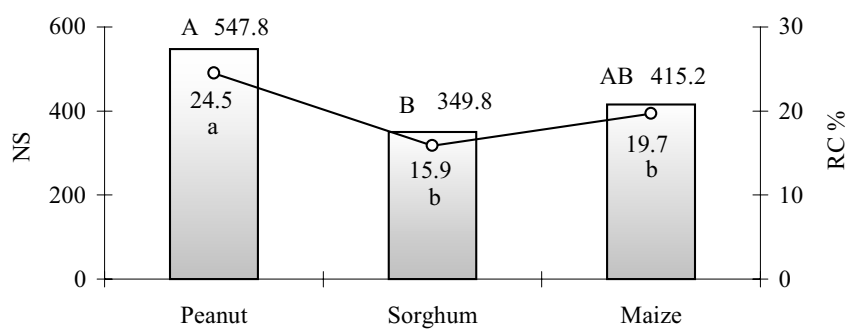

Figure 1. Numbers of spores (NS) and \% root colonization (RC) observed in peanut, sorghum and maize cultivated in quartz sand. $n=6$; using Tukey's test, similar letters are not significantly different at the 5\% level; lower case letters compare $\%$ root colonization and upper case letters compare spore numbers. Bar graph corresponds to NS (A, B); line graph corresponds to $\mathrm{RC} \% \quad(\mathrm{a}, \mathrm{b})$. 
compounds have frequently been associated with attraction of the germ tubes of G. margarita and Glomus spp. (Tsai \& Phillips 1991, Bécard et al. 1992) to the roots. This may have favoured the occupation of the roots by AMF, by influencing spore germination and the growth of germ tubes.

Total number of spores - The numbers of spores varied with the host plant: peanut showed the highest number of spores, followed by maize and sorghum (table 1). Harinikumar \& Bagyaraj (1988) observed a larger production of spores and infective propagules of AMF in peanut than in the grass Eleusine coracana (L.) Gaertn. Similarly, studies of Saif (1986) and Howeler et al. (1987) demonstrated that legumes tend to promote the sporulation of AMF more effectively than grasses and this is in agreement with the data obtained in the present study. The median numbers of spores in rhizospheres of peanut, maize and sorghum were, respectively, 547.8, 415.2 and 349.8/100 g soil. The number of spores isolated from peanut was significantly higher than from sorghum, while maize presented an intermediate number of spores (figure 1).

In this investigation, root colonization and sporulation were apparently correlated; however, these processes are not necessarily dependent on each other and previously published data are ambiguous (Abbott \& Robson 1991, Douds 1994). For Acaulospora species it has been observed that intraradical development affects both the beginning of sporulation as well as the production of external hyphae (Gazey et al. 1992). Clapp et al. (1995), using molecular techniques, demonstrated a positive relationship between the distribution of spores and root colonization in Acaulospora and Scutellospora species under field conditions. More detailed works, carried out under controlled conditions, suggest that the production of spores is related more strongly to the length of root colonization than to the percent root colonization (Douds \& Schenck 1990, Gazey et al. 1992). Other papers showed that plants with finer roots favoured the sporulation of AMF (Kormanick et al. 1980), and yet others correlated the increased number of spores with the improved nutritional state of the plants (Louis \& Lim 1987).

It is possible that these varied responses are due to different specific compositions of the AMF communities, to the plant variety (Raju et al. 1990) and to distinct edaphic or climatic conditions (Rosendahl et al. 1990). It is important to remember that each fungus presents its own demand for photoassimilates, and the environmental conditions may affect the interactions of these organisms with the roots (Pearson \& Schweiger
1993) influencing indirectly fungal reproductive activity. AMF present: relative number of spores and relative frequency of occurrence - In the present study 14 species of AMF were identified: Acaulospora appendicula Spain, Sieverding \& Schenck, A. longula Spain \& Schenck, A. scrobiculata Trappe, Entrophospora colombiana Spain \& Schenck, Gigaspora decipiens Hall \& Abbott, Glomus claroideum Schenck \& Smith, G. clarum Nicolson \& Gerdemann, G. geosporum (Nicol. \& Gerd.) Walker, G. globiferum Koske \& Walker, G. macrocarpum Tulasne \& Tulasne, G. microaggregatum Koske, Gemma \& Olexia, G. mosseae Nicolson \& Gerdemann, Scutellospora heterogama (Nicol. \& Gerd.) Walker \& Sanders and $S$. persica (Koske \& Walker) Walker \& Sanders. Two species detected in the initial inoculum (G. margarita and $G$. invermaium) did not sporulate, but an additional seven species were detected that were not sporulating in the initial inoculum. In a previous study (data not shown), 25 species of AMF were detected in the soil samples that were used as inoculum in this experiment. Apparently the inoculum had propagules of greater number of species than those identified by the evaluation of spores. Probably, substrate and host plants triggered the sporulation of more tolerant species to the new growth conditions, altering the number of AFM species detected. The smaller diversity of species, when compared to that observed in field experiments is probably due to the inappropriate conditions for plant growth. The acidity of the substrate and the low availability of mineral nutrients still allowed the plants to grow and to complete their reproductive cycle, but this development was quite precarious. There was a slowdown of flowering and fructification, and also a reduction of the vigour of these plants, according to personal observations, in spite of being periodically supplemented with nutrient solution. Chilvers \& Daft (1982) also observed a lower diversity of AMF when the vigour of the photobionts was reduced. The low $\mathrm{pH}$ may also have influenced the diversity since it may select those species that are better adapted to these conditions.

Seven species of AMF were identified in peanut (table 2), with E. colombiana being the dominant species (66.6\% of spores) and the most frequently observed (100\% of samples). Glomus macrocarpum, A. longula and $G$. claroideum also were frequently detected, with frequencies varying from $66.6 \%$ (the last two species) to $83.3 \%$ (the first species).

In relation to the number of spores, we could also observe three distinct groups of species: 1) species with low number of spores (4-13/100 g soil); 2) species with 
high number of spores (365/100 g soil); and 3) species with intermediate number of spores $(41-71 / 100 \mathrm{~g}$ soil) (table 2).

Acaulosporaceae was the most representative family ( $81.8 \%)$, followed by Glomaceae (17.4\%) and Gigasporaceae $(0.8 \%)$ in terms of abundance of spores (figure 2). With regard to the diversity of species, Acaulosporaceae was equally dominant with Glomaceae (both of them with $42.9 \%$ ), followed by Gigasporaceae (14.2\%). Only three species in the Gigasporaceae were detected. Previously, Sieverding (1991) proposed that the host plant influences differentially the development of the AMF species. This author suggested that Scutellospora species did not develop as well in legumes as did Acaulospora species, failing in inter-specific competition and root colonization processes.
When peanut was cultivated under monoculture in the same area where we cropped maize, up to 22 species of AMF were isolated (Bononi et al. 1988, Barbosa \& Santos 1991), G. macrocarpum being the only one common to both experiments. Again it is observed that field growth conditions are more adequate to the AMF to develop and diversify. Probably, G. macrocarpum is the most distributed and persistent species within the AMF community from that region.

In our study, G. macrocarpum occurred at low numbers of spores in peanut rhizospheres, however it was found in almost all the samples. The best represented species, E. colombiana, may have been favoured by the low $\mathrm{pH}$ from the substratum, since its occurrence is generally associated with acid soils (Abbott \& Robson 1977), and also by the suggested affinity between species of Acaulosporaceae and legumes (Sieverding 1991).

Table 2. Relationships between species of AMF isolated from rhizospheres of peanut, sorghum and maize cultivated in quartz sand. NS = specific number of spores; RNS = relative number of spores; RFO = relative frequency of occurrence.

\begin{tabular}{|c|c|c|c|c|c|c|c|c|c|}
\hline \multirow[t]{2}{*}{ AMF species } & \multicolumn{3}{|c|}{ Peanut } & \multicolumn{3}{|c|}{ Sorghum } & \multicolumn{3}{|c|}{ Maize } \\
\hline & $\mathrm{NS}^{\mathrm{a}}$ & $\mathrm{RNS}^{\mathrm{b}}$ & $\mathrm{RFO}^{\mathrm{b}}$ & $\mathrm{NS}^{\mathrm{a}}$ & $\mathrm{RNS}^{\mathrm{b}}$ & $\mathrm{RFO}^{\mathrm{b}}$ & $\mathrm{NS}^{\mathrm{a}}$ & $\mathrm{RNS}^{\mathrm{b}}$ & $\mathrm{RFO}^{\mathrm{b}}$ \\
\hline A. appendicula ${ }^{\mathrm{c}}$ III & $13 *$ & 2.3 & 33.3 & - & - & - & 6* & 1.5 & 50.0 \\
\hline A. longula $\mathrm{I}$ & 716 & 12.9 & 66.6 & $10 *$ & 2.8 & 50.0 & $193 *$ & 46.5 & 100.0 \\
\hline A. scrobiculata IV & - & - & - & $3 *$ & 0.9 & 16.7 & - & - & - \\
\hline E. colombiana I & 365 & 66.6 & 100.0 & $27 *$ & 7.5 & 50.0 & $64 \%$ & 15.4 & 83.3 \\
\hline G. claroideum II & 410 & 7.5 & 66.6 & 780 & 22.4 & 83.3 & 720 & 17.4 & 66.6 \\
\hline G. clarum III & $4 *$ & 0.8 & 16.7 & $28 *$ & 8.4 & 50.0 & - & - & - \\
\hline G. geosporum II & - & - & - & $88 \div$ & 25.2 & 100 & $12 *$ & 2.9 & 50.0 \\
\hline G. globiferum IV & - & - & - & $7 *$ & 1.9 & 33.3 & - & - & - \\
\hline G. macrocarpum II & $50 \div$ & 9.1 & 83.3 & $10 *$ & 2.8 & 33.3 & $21 *$ & 4.9 & 66.6 \\
\hline G. microaggregatum II & - & - & - & $82 \div$ & 23.4 & 50.0 & $29 *$ & 7.0 & 50.0 \\
\hline G. mosseae IV & - & - & - & $3 *$ & 0.9 & 16.7 & - & - & - \\
\hline G. decipiens III & $4 *$ & 0.8 & 16.7 & $7 *$ & 1.9 & 16.7 & $5 *$ & 1.2 & 33.3 \\
\hline S. heterogama III & - & - & - & $7 *$ & 1.9 & 33.3 & $7 *$ & 1.7 & 50.0 \\
\hline S. persica IV & - & - & - & - & - & - & $6 *$ & 1.5 & 50.0 \\
\hline Indices & & Peanut & & & Sorghul & & & Maize & \\
\hline Richness & & 7 & & & 12 & & & 10 & \\
\hline Dominance & & 0.47 & & & 0.18 & & & 0.25 & \\
\hline Diversity & & 1.16 & & & 1.89 & & & 1.93 & \\
\hline Equability & & 2.26 & & & 4.68 & & & 4.44 & \\
\hline
\end{tabular}

* = low NS; $;$ : intermediate NS; = high NS. I includes AMF species present in all host plants, with low, intermediate or high NS; II includes species present in more than one host plant, with low to intermediate NS; III includes species present in more than one host plant, with very low NS; IV includes species present in only one host plant, with very low NS. ${ }^{a} \mathrm{n}=6$ replicates; ${ }^{\mathrm{b}}$ relative number of spores and relative frequency of occurrence expressed in percent values; ${ }^{\mathrm{c}} A$. appendicula is synonymous of A. gerdemannii (Morton et al. 1997). 


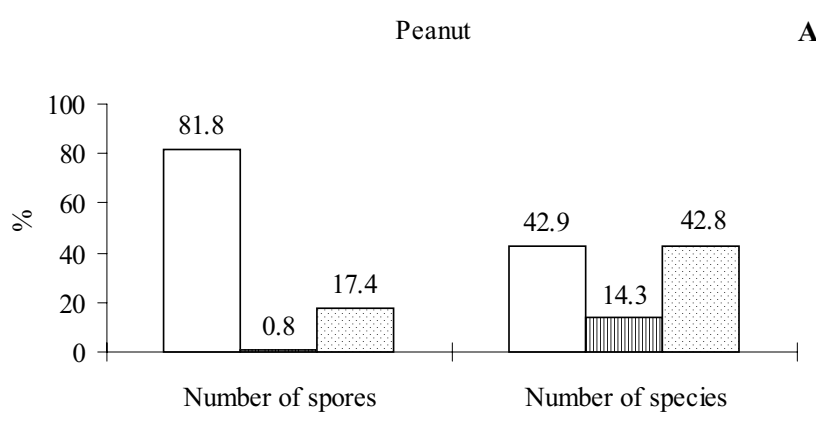

Sorghum
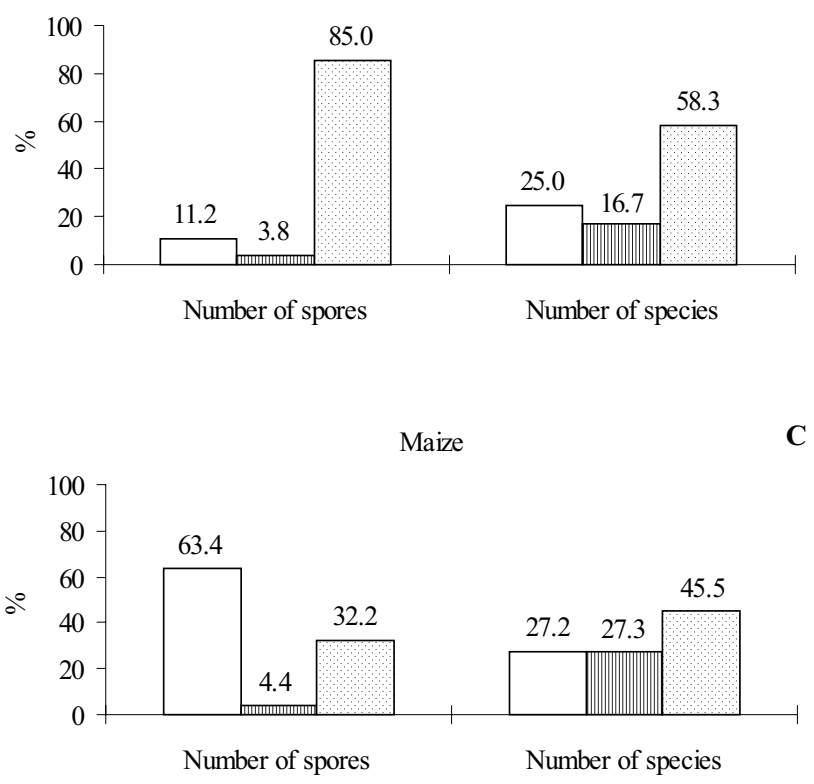

Figure 2. Significance of AMF families, in terms of number of spores and number of species, in peanut, sorghum and maize cultivated in quartz sand. A- Peanut, B- Sorghum and C- Maize. $\square$ Acaulosporaceae $\llbracket \|$ Gigasporaceae $\because \because$ Glomaceae.

In other experiments carried out on field-cultivated peanut, G. macrocarpum was the dominant species, followed by G. fecundisporum (Bononi et al. 1988), and $S$. heterogama and S. gilmorei (Barbosa \& Santos 1991).

The rhizospheres of nitrogen-fixing legumes are much more acidic than those of other plants, as demonstrated for several cultivated monocotyledons and dicotyledons (Marshner \& Römheld 1983). Great differences in the rhizospheric $\mathrm{pH}$ of several species growing in a same soil have been observed, as well as differences exceeding two $\mathrm{pH}$ units along the roots of the same plant (Marshner \& Römheld 1983). In general, dicotyledons tend to absorb more cations than anions from edaphic solution, so that rhizosphere acidification is usually higher than in monocotyledons, which preserve a ratio of cation to anion close to one.

Twelve species of AMF were identified in sorghum (table 2), being G. geosporum (25.2\% of spores), G. microaggregatum (23.4\%) and G. claroideum $(22.4 \%)$ the dominant species. Glomus microaggregatum was present in half of the samples, while G. geosporum and G. claroideum showed a broader distribution (100 and $83.3 \%$, respectively). Glomaceae was the family with the highest number of spores $(85 \%)$ and diversity of species $(58.3 \%)$, followed by Acaulosporaceae (11.2 and 25\%, respectively) and Gigasporaceae (3.8 and 16.7\%, respectively) (figure 2). Additionally, we observed only two groups of species, according to number of spores: the first of them aggregated species with low number of spores (3-28/100 g soil) and the second included species of AMF with intermediate number of spores (78-88/100 g soil) (table 2).

Ten species were identified in maize (table 2), with a preponderance of $A$. longula $(46.5 \%), G$. claroideum $(17.4 \%)$ and E. colombiana. (15.4\%). These were the most frequent species (present in 100, 83.3 and 66.6\% of the samples, respectively), along with G. macrocarpum (66.6\%). Acaulosporaceae was the family with the highest number of spores $(63.4 \%)$, followed by Glomaceae (32.2\%) and Acaulosporaceae $(4.4 \%)$. The greatest number of species was detected in Glomaceae (45.4\%), followed by Acaulosporaceae and Gigasporaceae (each in $27.3 \%$ of samples) (figure 2 ). In this host plant, we could also observe three groups of species: 1) species of AMF with low number of spores (5-29/100 g soil); 2) species with high number of spores (193/100 g soil); and 3) species with intermediate number of spores (64-72/100 g soil) (table 2).

Sorghum and maize appear to be less selective for the AMF species present in the inoculum, permitting a wide proliferation of these organisms in their roots and allowing a richer and more varied community to develop (table 2). The larger root density, extension and branching of the roots observed for grasses (Robertson et al. 1980), could have favoured the formation of more numerous infection points resulting in contact with greater number of spores, showing through out the substrate. With a larger root area to explore, the infection points and posterior intraradical colonization may have been "diluted", explaining the smaller root percent of colonization rates observed in these plants (table 1).

Despite the higher number of AMF species on sorghum and maize than peanut, the qualitative and quantitative compositions of their communities were also 
different (table 2). The small dominance of species observed in the community established in sorghum may be due to at least two factors: a) the low $\mathrm{pH}$ permitted only the establishment of AMF able to support germination in acid soil; and $b$ ) the plant favoured the association of a more compatible group (for example, $G$. geosporum, G. microaggregatum and $G$. claroideum).

Although sorghum is commonly used for the multiplication of AMF spores (Hetrick \& Bloom 1986, Kormanick et al. 1980, Morton et al. 1993) many studies have demonstrated that this host plant does not support good sporulation of some species, including G. fasciculatum (Bagyaraj \& Manjunath 1980), G. macrocarpum, G. claroideum, G. etunicatum (Struble \& Skipper 1988) and G. clarum (Talukdar \& Germida 1993). Our data contradict the previous results for G. clarum and G. claroideum, since these species had the greatest numbers of spores in this host plant.

Even though, for each fungal species there was one host plant that supported the greatest sporulation (table 2), we could verify four general groups of AMF species, according to their presence and abundance in the host plants. The first group was composed by species (A. longula and E. colombiana) that were present in rhizospheres of all three host plants, although the number of spores differed for each host. The second group included species that were present in more than one host plant and in at least in one of them, found favourable conditions for an intermediate sporulation (40-90 spores). This group includes G. microaggregatum (82 spores in sorghum), G. geosporum (88 spores in sorghum), G. macrocarpum (50 spores in peanut) and G. claroideum ( 78 and 72 spores, in sorghum and peanut respectively). The third group also had species isolated in more of one host plant, however, they had low number of spores (A. appendicula, G. decipiens, G. clarum, $S$. heterogama) in all host plant. The last group was comprised of species found on one host plant and always with very low numbers of spores (A. scrobiculata, G. globiferum, G. mosseae, S. persica).

Ecological indices - The indices richness and dominance were negatively correlated in peanut (table 2), suggesting that the environmental conditions were unsuitable for the diversification of AMF in this plant. From seven observed fungal species, just one (Entrophospora colombiana) showed high number of spores $(365 / 100 \mathrm{~g}$ soil or $66.6 \%$ of the total number of spores). This dominance of E. colombiana in peanut rhizospheres may be due to its adaptation to the environmental conditions, as well as to its high competitiveness and/or reproductive capacity (Sieverding \& Toro 1986, 1987).

In this study, richness and equability were positively correlated in sorghum with the community of AMF more uniform and richer. It was verified that this uniformity was favoured by the development of species with low and intermediate sporulating capacity (nine species with 3-28 spores/100 $\mathrm{g}$ of soil, and three species with spores varying from 78 to 88 in each $100 \mathrm{~g}$ of soil), as shown in table 2 . Thus, the species with higher number of spores (G. geosporum) had only $25.2 \%$ of the total number of spores.

Although sorghum presented more species of AMF (12 vs. 10, in maize), the diversity, expressed by Shannon-Weaver's index, was slightly higher in maize (table 2), and this could be related to the abundance of each species inside the communities in the samples. From those ten species isolated from maize, seven showed low number of spores $(20.7 \%$ of the total number of spores), two had an intermediate number of spores $(32.8 \%)$ and just one exhibited high number, totalling $46.5 \%$ of the spore population. In sorghum, in spite of the community of AMF having higher equability, the group of species with higher numbers of spores comprised $71 \%$ of the total number of spores (table 2). According to Pielou (1969) and Kricher (1972), diversity increases when the abundance of species becomes more uniform, and it may explain the higher diversity index obtained in maize.

Our data show that the use of grasses (sorghum and maize) in the multiplication of AMF spores in pots made greater collection of species established in the cultivated field possible, while the use of a leguminous plant (peanut) sustained high sporulation of these fungi. Another important piece of information that this study shows is that the substrate used (river sand) restricted AMF community diversity, probably by selecting species adapted to an acid $\mathrm{pH}$ and low fertility. Therewith, we suggest the following procedures for the multiplication of AMF spores in pots: a) use of mixed substrate (sand + soil); b) use of sorghum and maize for the trapping of spores coming from the field, when the objective of the study is a survey of species diversity; c) use of the peanut for the multiplication of spores, when the objective is inoculum production. We must point out that many other host plants may and should be tested to broaden the knowledge and the possibilities of their use as AMF multiplicators.

Acknowledgements - We would like to thank CNPq (Conselho Nacional de Apoio à Pesquisa Científica) for providing a grant to the first author, and acknowledge the help of the field 
workers from the Biological Reserve and Experimental Station of Moji-Guaçu for accompanying the present experiment. We are indebted to Dr. Walter Valerio Filho from Universidade Estadual Paulista, Faculdade de Engenharia de Ilha Solteira for accomplishing the statistical analysis of the data.

\section{References}

ABBOTT, L.K. \& ROBSON, A.D. 1977. The distribution and abundance of vesicular-arbuscular endophytes in some western Australian soils. Australian Journal of Botany 25:515-522.

ABBOTT, L.K. \& ROBSON, A.D. 1991. Field management of VA mycorrhizal fungi. In The rhizosphere and plant growth (D.L. Keister \& P.B. Oregan, eds.). Kluwer Academic Publishers, Dordrecht, p.355-362.

BAGYARAJ, D.J. \& MANJUNATH, A. 1980. Selection of a suitable host for mass production of VA mycorrhizal inoculum. Plant and Soil 55:495-498.

BAPTISTA, E.A. 1988. Influência de fatores edáficos no cerrado da reserva biológica de Mogi-Guaçu, SP. Tese de doutorado, Universidade de São Paulo, Piracicaba.

BARBOSA, L.M. \& SANTOS, M.R.O. 1991. Estudos qualiquantitativos da ocorrência de fungos micorrízicos vesículo-arbusculares (MVA) na cultura do amendoinzeiro (Arachis hypogaea L.) sob mato-competição. Hoehnea 18:189-200.

BÉCARD, G., DOUDS, D.D. \& PFEIFFER, P.E. 1992. Extensive in vitro hyphal growth of vesicular-arbuscular mycorrhizal fungi in the presence of $\mathrm{CO}_{2}$ and flavonoids. Applied and Environmental Microbiology 58:821-825.

BETHLENFALVAY, G.J. \& PACOVSKY, R.S. 1983. Light effects in mycorrhizal soybeans. Plant Physiology 73:969-972.

BONONI, V.L.R., BARBOSA, L.M. \& VIRIATO, A. 1988. Micorrizas vesículo-arbusculares em amendoim e em plantas invasoras da cultura. Hoehnea 15:1-9.

CHILVERS, M.T. \& DAFT, M.J.F. 1982. Effects of low temperature on development of the vesicular-arbuscular mycorrhizal association between Glomus caledonius and Allium cepa. Transactions of the British Mycological Society 79:153-157.

CLAPP, J.P., YOUNG, J.P.W., MERRYWEATHER, J. \& FITTER, A.H. 1995. Diversity of fungal symbionts in arbuscular mycorrhizas from a natural community. New Phytologist 130:259-265.

D'ARCY-LAMETA, A. 1988. Study of soybean and lentil root exudates. II. Identification of some polyphenolic compounds, related with plant physiology. Plant and Soil 92:113-123.

DOUDS, D.D. 1994. Relationships between hyphal and arbuscular colonization and sporulation in mycorrhiza of Paspalum notatum Flugge. New Phytologist 126:233-237.

DOUDS, D.D. \& SCHENCK, N.C. 1990. Relationship of colonization and sporulation by VA mycorrhizal fungi to plant nutrient and carbohydrate contents. New Phytologist 116:621-627.
GAZEY, C., ABBOTT, L.K. \& ROBSON, A.D. 1992. The rate of development of mycorrhizas affects the onset of sporulation and production of external hyphae by two species of Acaulospora. Mycological Research 96:643-650.

GERDEMANN, J.W. \& NICOLSON, T.H. 1963. Spores of mycorrhizal Endogone species, extracted from soil by wetsieving and decanting. Transactions of the British Mycological Society 46:235-244.

GIOVANNETTI, M. \& MOSSE, B. 1980. An evaluation of techniques for measuring vesicular-arbuscular mycorrhizal infection in roots. New Phytologist 84:489-500.

GOMES-DA-COSTA, S.M. 1993. Fungos micorrízicos arbusculares em monoculturas e rotações de milho (Zea mays L.) e soja (Glycine max (L.) Merrill. Tese de doutorado, Universidade Estadual Paulista, Rio Claro.

GRACIOLLI, L.A. 1992. Efeito do biossuper na cultura de milho (Zea mays L.) em latossolo vermelho-escuro, no município de Selvíria, MS. Tese de doutorado, Universidade Estadual Paulista, Rio Claro.

HARINIKUMAR, K.M. \& BAGYARAJ, D.J. 1988. Effect of crop rotation on native vesicular arbuscular mycorrhizal propagules in soil. Plant and Soil 110:77-80.

HETRICK, B.A.D. \& BLOOM, J. 1986. Influence of host plant on production and colonization ability of vesicular-arbuscular mycorrhizal spores. Mycologia 78:32-36.

HOWELER, R.H., SIEVERDING, E. \& SAIF, S.R. 1987. Practical aspects of mycorrhizal technology in some tropical crops and pastures. Plant and Soil 100:249-283.

KORMANICK, P.P., BRYAN, W.C. \& SCHULTZ, R.C. 1980. Increasing endomycorrhizal fungus inoculum in forest nursery soil with cover crops. Southern Journal of Applied Forestry 4:51-153.

KRICHER, J.C. 1972. Bird species diversity: the effect of species richness and equitability on the diversity index. Ecology 53:278-282.

LACKIE, S.M., GARRIOK, M.L.,PETERSON, R.L. \& BOWLEY, S.R. 1987. Influence of host plant on the morphology of the vesicular-arbuscular mycorrhizal fungus Glomus versiforme (Daniels \& Trappe) Berch. Symbiosis 3:147-158.

LOUIS, I.M. \& LIM, G. 1987. Spore density and root colonization of vesicular-arbuscular mycorrhizas in tropical soil. Transactions of the British Mycological Society 88:207-212.

MARSHNER, H. \& RÖMHELD, V. 1983. In vivo measurement of root-induced $\mathrm{pH}$ changes at the soil-root interface: effect of plant species and nitrogen source. Zeitschrift fuer Pflanzenphysiologie 111:241-251.

MORTON, J.B., BENTIVENGA, S.P. \& WHEELER, W.W. 1993. Germ plasm in the International Collection of Arbuscular and Vesicular-Arbuscular Mycorrhizal Fungi (INVAM) and procedures for culture development, documentation and storage. Mycotaxon 48:491-528.

MORTON, J.B., BEVER, J.D. \& PFLEGER, F.L. 1997. Taxonomy of Acaulospora gerdemannii and Glomus leptotichum, synanomorphs of an arbuscular mycorrhizal fungus in Glomales. Mycological Research 101:625-631. 
MOSSE, B. 1975. Specificity in VA mycorrhizas. In Endomycorrhizas (F.E. Sanders, B. Mosse \& P.B. Tinker, eds.). Academic Press, London, p.409-484.

PEARSON, J.N. \& SCHWEIGER, P. 1993. Scutellospora calospora (Nicol. \& Gerd.) Walker \& Sanders associated with subterraneum clover: dynamics of colonization, sporulation and soluble carbohydrates. New Phytologist 124:215-219.

PHILLIPS, J.M. \& HAYMAN, D.S. 1970. Improved procedures for clearing roots for rapid assessment of infection. Transactions of the British Mycological Society 55:158-161.

PIELOU, E.C. 1969. An introduction to mathematical ecology. Wiley-Interscience, New York.

PIELOU, E.C. 1975. Ecological diversity. John Wiley \& Sons, New York.

RAJU, P.S., CLARKE, R.B., ELLIS, J.R., DUNCAN, R.R. \& MARANVILLE, J.W. 1990. Benefit and cost analysis and phosphorus efficiency of VA mycorrhizal fungi colonization with sorghum (Sorghum bicolor) genotypes grown at varied phosphorus levels. Plant and Soil 124:199-204.

ROBERTSON, W.K., HAMMOND, L.C., JOHNSON, J.T. \& BOOTE, K.J. 1980. Effects of plant water stress on root distribution of corn, soybeans, and peanuts in a sandy soil. Agronomy Journal 72:548-550.

ROSENDAHL, S., ROSENDAHL, C.N. \& SOCHTING, U. 1990. Distribution of VA mycorrhizal community. Agriculture, Environments and Ecosystems 29:329-336.

SAIF, S.R. 1986. Vesicular-arbuscular mycorrhizae in tropical forage species as influenced by season, soil texture, fertilizers, host species and ecotypes. Angewandte Botanik 60:125-139.

SAME, B.I., ROBSON, A.D. \& ABBOTT, L.K. 1983. Phosphorus, soluble carbohydrates and endomycorrhizal infection. Soil Biology and Biochemistry 15:593-597.

SHANNON, C.E. \& WEAVER, W.1949. The mathematical theory of communication. University of Illinois Press, Urbana.
SIEVERDING, E. 1991. Plant protection practices with pesticides. In Vesicular-arbuscular mycorrhiza management in tropical agrosystems. (E. Sieverding, ed.). Technical Cooperation, Federal Republic of Germany, Eschborn, p.165-182.

SIEVERDING, E. \& TORO, T.S. 1986. The genus Entrophospora in Colombia. In Physiological and genetical aspects of mycorrhizae (V. Gianinazzi-Pearson \& S. Gianinazzi, eds.). INRA, Paris, p.621-626.

SIEVERDING, E. \& TORO, T.S. 1987. Growth of coffee and tea plants in nurseries inoculated with different VAM fungal species. In Mycorrhizae in the next decade, practical applications and research priorities (D.M. Sylvia, L.L. Hung \& J.H. Graham, eds.). Proceedings of the 7th NACOM., IFAS. University of Florida, Gainesville, p. 58.

SIMPSON, D. \& DAFT, M.J. 1990. Spore production and mycorrhizal development in various tropical crop hosts infected with Glomus clarum. Plant and Soil 121:171-178.

SIMPSON, E.H. 1949. Measurement of diversity. Nature 163: 688 .

SMITH, S.E. \& READ, D.J. 1997. Vesicular-arbuscular mycorrhizas. In Mycorrhizal symbiosis (S.E. Smith \& D.J. Read, eds.), $2^{\text {nd }}$. Academic Press, London, p.9-160.

STRUBLE, J.E. \& SKIPPER, H.D. 1988. Vesicular-arbuscular mycorrhizal fungal spore production as influenced by plant species. Plant and Soil 109:277-280.

TALUKDAR, N.C. \& GERMIDA, J.J. 1993. Propagation and storage of vesicular-arbuscular mycorrhizal fungi isolated from Saskatchewan agricultural soils. Canadian Journal of Botany 71:1328-1335.

TSAI, S.M. \& PHILLIPS, D.A. 1991. Flavonoids released naturally from alfalfa promote development of symbiotic Glomus spores in vitro. Applied and Environmental Microbiology 57:1485-1488. 